\title{
DEMOCRACY AND JUSTICIABILITY OF THE RIGHT TO EDUCATION - THE BRAZILIAN EXPERIENCE
}

Nina Beatriz Ranieri

University of São Paulo, Brazil.

nranieri@usp.br

Received: 2015-11-08. Accepted:2016-05-18.

\begin{abstract}
Democratic regimes establish themselves to the extent to which they are accepted by the majority of the population living under them. This acceptance is translated into a knowledge of and trust in their respective political and legal institutions. Quality education is relevant to democratic governance and citizenship building, as it provides access to the cognitive tools needed for significant political participation. This paper analyzes the interactions between democracy and quality education in the light of judicial proceedings being applied to the right to education, focusing on Brazilian Supreme Court (STF) activities in the period between 2000 and 2010 .
\end{abstract}

Keywords: Democracy - Right to education - Public Policies Constitutional law

\section{INTRODUCTION}

Recent political science studies identified the trust of citizens in democratic institutions as one of the essential components of consolidation and improvement of democracies. Reinforcing these findings, same studies show that lack of trust in democratic institutions, as well as lack of knowledge of how they operate, pose a risk to compliance with the norms, weakens political and legal institutions, and limit their legitimacy. These investigations have concluded, therefore, that trusting democratic institutions is related to the quality of the democracy. In other words: democracy will not be fully established until it is accepted by political leaders and the citizens as the only possible way of exercising state authority. More: in order for the democratic 
system and its institutions to function well, their values, principles, and entities must be followed by the majority of citizens, unconditionally, as essential elements of political citizenship.

In Political Science, three fundamental reasons raise from the recent launch of studies on the quality of democracy. First: improving the quality of democracy is a duty, derived from principles of Constitutional Rule of Law, because the protection of fundamental rights strictly depends on the quality of a democracy. Second: continuous improvement of democracy strengthens the necessary requisites for the legitimacy of states, especially after a transition from a non-democratic regime, as is the case of Brazil. Third: even in states where democracy is already established, there will always be room for improvement.

Until recently, it was not obvious in Political Science that the relationship between democracy, citizenship, and trust in democratic institutions is relevant to the theory of democracy. Although competitive elections and political parties, which express diversity and plurality in society, are indispensable to contemporary democracies, they do not ensure a quality democracy, nor do they exhaust the democratic order. Building effective democracies and quality democracies is a serious challenge, which depends on the participation of the people. The more the people lack hope and satisfaction toward their democratic regimes, the greater the difficulty to strengthen the democracy they live in. Additionally, institutional inefficiency towards social needs, fraud perpetration, corruption, and disrespect of citizens' rights negatively affect society compliance with the Rule of Law.

These findings also apply to the Brazilian case. Between the year 1989 - when the first direct presidential elections were held in Brazil pursuant to the 1988 Constitution - and 2010, the appreciation of democracy by the population grew by $21 \%$ (from $43.6 \%$ to $64.8 \%$ ); in the same period, the number of people unable to define "democracy" decreased by $13 \%$ (from $38.8 \%$ to $25.5 \%$ ). In parallel, there was an increasing negative perception, by the population, of government institutions concerning income levels, schooling and age brackets. This was found in relation to the three branches of power and also concerning political parties, and was mainly a result of corruption charges, embezzlement of public resources, and the poor quality of public services. In June 2013, the protests and marches that swept Brazil confirmed this negative trend. On the other hand, according to a study by MOISÉS (2010) aimed at assessing the satisfaction rate of the population in regard to Brazilian political institutions, it was found that most Brazilians believe in the statement that a democracy can do without congress and political parties.

Although Brazilian democracy is established, and grounded on alternating political power, and political stability, these findings 
show that the negative perception of state institutions has a positive influence on the citizens' willingness to take part in electing their representative. Moreover, negative perception has negative effects on political participation, creating alienation and contributing to the lack of interest on the part of the majority of the population. In short: in the twenty five years of our democratic regime (a period as long as the previous military dictatorship), Brazil has become an "electoral democracy", but not an "effective democracy" in which would predominate issues - other than voting - such as rights, rule of law, and a broader understanding of participation possibilities inherent to the exercise of citizenship. Therefore, the lack of trust Brazilian citizens show towards their government institutions, and the lack of satisfaction with the performance of the democratic system in place, paradoxically coexist with their support of democracy.

There are consistent explanations for this situation. Despite the undeniable advances triggered by the 1988 Constitution and the significant improvement in social indicators in comparison to the figures of previous years, social indicators in Brazil are still considered poor. Social reforms have been left incomplete, and there is a lot of room for improvement in terms of efficiency and equality. Social and economic equality have not been achieved so far. Such a situation is the result of severe poverty and low education rates, among other factors. This context explains the demand for citizenship, identified as the axis upon which rests the yearning for inclusion and social emancipation, common to complex, unequal, and sui generis societies, such as the Brazilian one. These demands outshine discussions on public policies, politics and democratization, which in some circumstances have reached the courts.

The meager social results do not, in any way, do justice to the intensity of the changes, which, despite the lack of major reforms, have transformed the profile of the Brazilian Social State in several aspects, such as the consolidation of citizenship. The positive changes are primarily due to four conditions created by the Constitution: valuation of social rights and their universalization; decentralization of government authority; formulation of new parameters for resources allocation; and redefinition of public-private relations in order to provide and finance social goods and services. This can be observed in the field of education.

Twenty-five years after the Constitution, progress is considerable regarding educational levels for the population in general and the youth in particular. The country has practically achieved universal primary education $^{1}$ (the basic educational system, following the tradition of

1 In $1988,84,02 \%$ of the children between 7 and 14 years old were enrolled in primary education; in 2012, the percentage of enrollments achieved 98, 52\%. Cf. http://www.ipeadata. gov.br/ 
Brazilian federalism, was not in the hands of the federal government but in those of the states). The role of both Executive and Legislative in this period is particularly relevant, considering the one-hundred-year delay in terms of education in Brazil, notably in terms of public education. This is especially relevant if one compares to other Latin American countries, such as Argentina and Uruguay, both of which, at the beginning of the twentieth century, had a universalized elementary education ${ }^{2}$.

In the same period, it was noteworthy the role of the Courts in setting educational policies consistent with the constitutional provisions to guarantee the right to education. This was particularly effective after the enactment of the Education National Act - NEA (Law 9.394, the Lei de Diretrizes e Bases da Educação Nacional), a federal Law that applies common guidelines to all educational systems across the country. Influencing the Congress and the Executive, education laws cases, especially related to access to childcare, to increasing mandatory basic education and to set affirmative actions, have to be seen not as the end of the judicial procedures, but instead as solutions for common education problems.

The political role of the courts is a recent phenomenon in Brazil, also derived from the 1988 Constitution. The valuation of social rights and their universalization, mentioned above, are the corner stones of this new role, influenced by ethical values. ${ }^{3}$ Several questions arise from this circumstance: to what extent the independence of the judiciary may be detrimental to democracy, considering the unpredictable effects of case laws on democratic politics. Should the Judiciary, which is not elected and politically irresponsible, make decisions on social rights that have to be implemented by and at the expense of the Executive? Is this democratically desirable? Moreover, traditionally, wealthy citizens tend to have greater access to the courts. By contrast, in contemporary democratic societies, law is both a tool for achieving social justice and social tensions solution mechanism, in the path of John Rawls' theory of justice as fairness (A Theory of Justice, 1971). This current regards the political activity of the judiciary as a tool for deepening democracy. This debate is not new and has already been consider by several authors (Waldron, 2006; Gloppen, 2008; Maccann, 2010, among others).

2 Cf. Fausto, Boris \& Fernando Devoto, Brasil e Argentina - Um Ensaio de Historia Comparada (1850-2002), São Paulo: Editora 34, 2004, p. 50 ff.. See also Marcilio, Maria Luiza, História da Educação em São Paulo e no Brasil, São Paulo: Imprensa Oficial, 2005, among others.

3 The opening of the Law to ethical and social values gave rise to the democratic European Constitutions of the post war, in particular: the Fundamental Law of Bonn (1948), the Constitution of Italian Republic (1948), the Spanish Constitution (1978) and the Constitution Portuguese (1976), in which human rights norms are the expressions of ethical and social values; as such, these norms are under strict supervision by Constitutional Courts. The Brazilian Constitution of 1988 was written under the influence of this theory. 
However, it is undeniable that the exercise of democracy presupposes forms of organization to prevent arbitrary decisions and allow the participation of citizens. In the absence of legislative or government activity, or in addition to them, lawsuits in education might be a strategy to guarantee equitable access to quality education.

This paper analyzes the interactions between democracy and quality education in the light of the justiciability of the right to education, with focus on the activity of the Brazilian Supreme Court (STF) and the Brazilian Superior Justice Court (STJ) in the period between 2000 and $2010 .{ }^{4}$ Partial conclusions show that jurisprudence might assure rights by influencing both Executive and Legislative; this would be made possible by the fact that the education legal regime is a regime of state performances, typical of social rights. Consequently, the constitutional definition of objectives, goals and priorities, combined with the accurate discrimination of competences, charges and revenues to Federation entities, and with the commitment of financial resources, should allow rights assurance to be attained in a medium term. To sustain these findings Part I focus on the relations between education and democracy; Part II presents some considerations on the justiciability of the right to education and Part III brings forward some conclusions about the role played by the Brazilian Superior Courts in establishing educational public policies. Throughout the paper, the adopted perspective is the quality of democracy. From this point of view, it analyzes the relationship between democratic principles, institutional processes, political participation, and the results of the work of democratic institutions. Consequently, the study of responsiveness and accountability of democratic governments in the studied period plays an important role in the analysis.

\section{EDUCATION AND DEMOCRACY}

Since mid-20th century, the literature on education has emphasized the relevance of education to a country's democratic governance and citizenship formation, and, in addition, has identified it as one of the main tools available for the State to reverse processes

4 Data sources and evidences in this paper are part of the research project Brazil: 25 years of democracy which aims at conducting research and critically analyzing this twenty-five-year period in Brazil (1988/2013) in the light of three main lines: (i) democratic institutions, (ii) relations between civil society and political culture, and (iii) public policies. Under the latter there is the study of the interaction between democracy, the right to education, and education policies. The project is led by the Research Center for Public Policy (NUPP), at the University of São Paulo, with the participation of teachers, researchers, and students of the University of São Paulo (USP), the University of Campinas (UNICAMP), the Pontifical Catholic University of São Paulo (PUCSP), and the Getúlio Vargas Foundation (FGVSP). 
replicating social inequalities ${ }^{5}$. Education, in this sense, means having access to the necessary cognitive tools enabling political participation (Lipset, 1959; Lazarsfeld et al., 1944; Converse, 1972; Dahl, 1967; Almond and Verba, 1968; Key, 1961). This understanding is expressed in article 205 of the 1988 Brazilian Constitution, which assigns to the educational process for the purpose of training citizens, among others. The right to education, as a result, is not ideologically unbiased. Its political core, according to the constitutional system as a whole, is the dissemination and promotion of republican and democratic principles. Education, therefore, is a political issue, an issue concerned with collective decision-making, the legitimacy, and the exercise of the law.

The relations between democracy, the right to education and public education policy revolve around a myriad of issues. The study of these relations involves the mobilization of theoretical skills from different areas of knowledge (Political Science, Social Sciences, Education, and Law etc.) as well as the ability to carry out an investigation from different perspectives at the same time. In the field of law, the research focuses on the analysis of the promotional function of the law ${ }^{6}$ that is, protecting and promoting the right to education. In fact, the legal debate on the implementation of public policies reveals the coercive power of the legal norm.

Despite the importance of the right to education for democracy consolidation in Brazil, the literature on the relationship between Law and Education, and on the role of the law in (the) enforcing public policies in education, is incipient. Since the last decade, legal scholars who have been writing about the right to education in both educational and legal approaches, have focused on more conjectural aspects namely, access, management, and financing conditions - rather than focusing on a more structural approach, in which subjects such as equity, quality, and efficiency are informed by the political element enshrined in the Constitution. In fact, systematic studies about the Brazilian educational system legal organization are a hardly at all explored field of study in the law. In the legal literature, there are no studies assessing the impact of legislation in implementing educational policies. Besides, laws on education are seen more as a branch of administrative law than an independent field having its own structures and categories (Ranieri, 2000). In the literature on education, studies have, for some time, shown that the law, in the relationship among education, society and the state, was being used more as a formalization technique than as an rationality tool, which could contribute to the goal of accomplishing

5 For a revision of this bibliography, see, among others, McMahon (2002) and Psacharopoulos (1988).

6 BOBBIO, Norberto. Da estrutura à função: novos estudos de teoria do Direito. Barueri: Manole, 2007. 
education (Cury, Horta \& Favero, 1996). This situation has preserved, in educational policy and practice, the centralizing features of Brazilian federalism in detriment of a more effective participation of society in educational issues.

Results of previous research (Ranieri, 2000) show that in the legal field the right to education is not perceived in its democratic dimension. However, it's materialization through judicial decisions have been showing new fields of affirmation in the democratic rule of law, favoring citizenship rights and popular participation, something especially important in a country with low popular perception of the value of democratic institutions and the normative force of the Constitution. In conclusion, the protection of the right to education through judicial mechanisms can be extremely effective in situations where public policy stems directly from the Constitution.

\section{THE JUSTICIABILITY OF THE RIGHT TO EDUCATION}

State obligations regarding the right to education have been interpreted under national, regional and international human rights law, establishing the right as justiciable. The right to education has been considered fully justiciable in many jurisdictions ${ }^{7}$, since it creates complex, intertwined obligations and responsibilities for multiple stakeholders. As the international human law states, States have the primary responsibility to realize the right to education for all individuals in their territories and subject to their jurisdiction. They must also establish an educational system respectful of the right to education and refrain from any action, which may prevent or limit access to education. In addition, States must ensure that it is respected and fulfilled both as entitlement in terms of universal access to basic education as well as empowerment in terms of acquisition of knowledge, skills and competencies and their quality and standard. ${ }^{8}$ As the Special Rapporteur for the right to education emphasized, the State obligations must be understood in terms of the right to quality education; these obligations also make State responsibility to provide necessary resources for its realization, including financing of education. ${ }^{9}$ Government policies and provisions of education both public and private are subject to review by judicial bodies; the role of adjudication is to ensure that the right to education is respected, protected and fulfilled. Its most basic

7 Fons Coomans, Justiciability of the Right to Education, Erasmus Law Review, Vol. 2, No. 4, pp. 427-443, 2009.

8 General Comment 13 on the Right to Education (article 13 of the Covenant), adopted by the Committee on Economic, Social and Cultural Rights at its twenty-first session in 1999. E/C.12/1999/10, 2 December 1999.

9 Report of the Special Rapporteur for the right to education - A/HRC/20/21, 2 May 2012. 
tenets, free and compulsory primary education for all, the progressive realization of secondary and tertiary education, and the immediate nondiscrimination in their application, are universally recognized.

In Brazil, the legal regime of the right to education is defined by the Federal Constitution and may be complemented by rules of Administrative Right; this is a very peculiar situation, since social rights, in general, have its legal regime established by Administrative Law. As such, situations of denial, violation or non-fulfilment of the State obligation related to the right to education could be examine by courts on grounds of constitutional provisions, as well as of international law. Available legal literature has been recognizing that any type of lawsuit (class actions, collective or merely individual) may be used to secure compliance by recourse to law courts. ${ }^{10}$

\section{Chart 1. Growth of the number of cases filed at the STF until 2009}

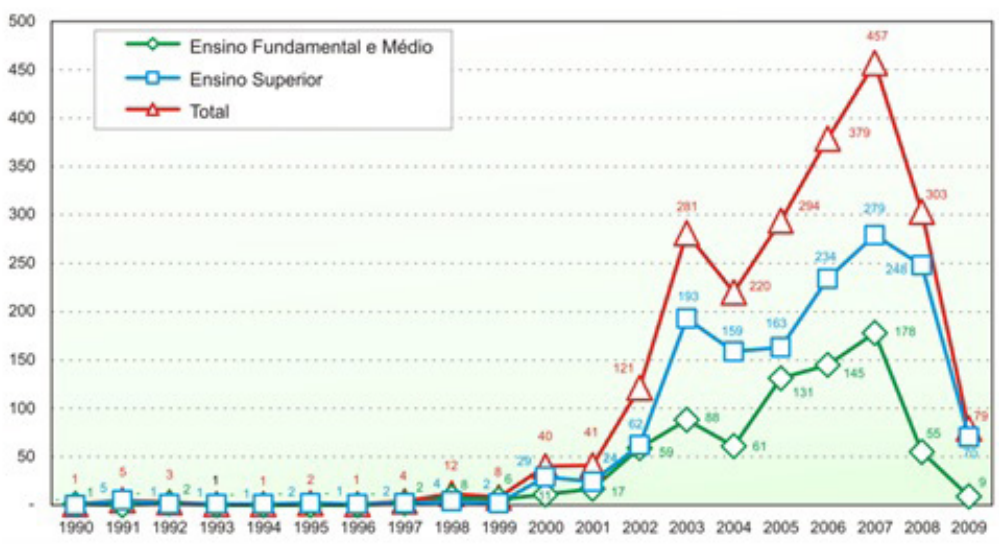

The right to education was a relatively marginal issue at the Brazilian Supreme Court before the 1988 Constitution, regardless of the fact that the court also had jurisdiction over issues concerning federal laws. Since then, the situation has changed substantially. Between 1988 and early 2013, the Supreme Court issued almost 4410 decisions, of which 4222 had been filed as of the year $2000^{11}$. Out of the said 4222 cases, by 2009, 2250 cases had been filed, and the remainder (about 2000 cases) were lodged at the Court in the last three years. Thus, it is possible to note a growing movement towards solving educationrelated issues through the court system, as shown in Chart 1. In this

10 See, for all, GRINOVER, Ada Pellegrini. O controle de políticas públicas pelo Poder Judiciário. In: SALLES, Carlos Alberto de (coord.). As grandes transformações do processo civil brasileiro - in honor of Prof. Kazuo Watanabe. São Paulo: Quartier Latin, 2009, pages 109-134.

11 Cf. www.stf.jus.br 
sense, there has been a noteworthy change in the terms of the content of court decisions in favor of the effectiveness of the right to education, especially with regard to basic education, with repercussions for the structures of a democratic state.

In the early 1990s, for example, lawsuits concerning tuition fees prevailed. These cases aimed to declare unconstitutional Law 8.039/90 (that controls the increase of the annual value of tuition fees), with grounds on the prohibition of State interference on the economic private sector. The Supreme Court declare the law constitutional, since it was issued to safeguard the right to education, protecting it from economic abuse on the part of the private sector, thus making it illegal for schools to penalize students in the event of breach of contract on the part of the latter (i.e. in the event students or their families failed to pay tuition for the year).

The content of the lawsuits present to the Court changed in the beginning of 2000. Several hypotheses may explain the increase in the number of lawsuits aiming at enforcing the right to education, especially in the context of early childhood education. Among them, the role of the Public Ministry under the 1988 Constitution and the consolidation of the civil class action to protect collective interests. Additionally, the creation of the Development Fund for Primary Education (Fundef) in 1996 enabled issues concerning funding, and increased the availability of basic education being solved by states and municipalities, and as a result, attaining universalization in many cases.$^{12}$

The role of the STF is particularly relevant considering that in 1988; part of the court's jurisdiction was assigned to the Brazilian Superior Court of Justice (STJ), created by the Constitution to ensure the adequate interpretation and uniformity of ordinary federal law in the cases adjudicated by the ordinary federal courts and state courts. This means that the STF decisions analyzed in this research, as of 2000, refer to constitutional matters only. This analysis' main goal is to identify significant references regarding the right to education and, in particular, to basic education, in decisions containing consistent interpretation and not merely constitutional law explanatory interpretation. The same is expected in relation to the Superior Court of Justice (STJ). In this case, the choice of the year 2000 as a starting point for reviewing the court's judgments is due to the enactment of the NEA in 1996 (Law 9 394/96).

Our attention is focused on basic education in view of the purposes of this level of education, notwithstanding the analysis of the problem of affirmative actions in higher education, given their peculiarities. The judgments and opinions issued by the Court, in addition to revealing the society degree of knowledge about the rights and guarantees provided in the Constitution, also situate the problem

12 On the universalization of basic education in Brazil see the 2008 UNESCO Global Monitoring Report available at http://unesdoc.unesco.org/images/0015/001547/154743e.pdf. 
of education in time and space. Besides, the decisions provide a broad overview on the progress of the realization of the right to education, above all by examining by examining the discretionary authority of legislature and government agents and their adequacy to the public policy expressed in the Constitution.

\section{The role played by the Superior Courts in establishing EDUCATIONAL PUBLIC POLICIES}

The research reviewed about 1600 cases concerning educational public policies. ${ }^{13}$ Partial results show that at least four evidences raised from the judicial activity in the public education area: (i) the Courts are becoming increasingly more accessible to the population in the protection and enforcement of the right to education; (ii) the Courts play a significant political role in establishing educational public policies; (iii) the Courts influence the National Congress' activities and also the Executive public expenditures agenda (however, the courts resist in recognizing themselves as legitimate and necessary parties in public policy review, including in demands that seek equalitarian distribution of resources and educational assets); (iv) the cases are notable for the continuing development of specific areas of education law that are raising new questions to courts to consider.

There are regional inequalities in terms of access to the courts: the largest number of cases was filed in South and Southeast regions (the most developed regions in Brazil) as well as the Federal District. Students are the main claimants/appellants in cases concerning individual disputes (most appeals filed by students aim at the recognition and accreditation of university degrees obtained abroad, especially degrees in medicine).

The number of cases revealed that state cases concerning access to primary school and pre-school, daycare included, represent the largest area of governance litigation. The remaining cases are aimed at solving individual claims (such as confirmation of degrees, equivalence of studies, transfer of public employees, and mandatory enrollment at the place of residence, penalties etc.). There aren't cases demanding the improvement of quality in education, a constant and prevailing issue in the June 2013 marches that swept the country.

The education law cases related to public daycare were notable for its social and political consequences. In São Paulo State Prosecutor's Office v. the City of Santo Andre, Appeal ${ }^{\circ} 410,715$ (2005), a case decided by the Supreme Court that tested the allowance of judicial activism in relation to the separation of powers clause, the constitutional

13 The cases review relied on courts databases and websites under the keywords "law and teaching" and "law and education". Duplicate results have not been deleted. 
controversy focused on the extent of the duty of the City of Santo Andrea wealthy municipality at the State of São Paulo - in guarantying universal access to daycare. In its defense, the Municipality claimed that daycare for children between 0 to 6 years old was neither a level of compulsory education nor a constitutional incumbency for local governments. In addition, the governmental budget was insufficient to create daycare new vacancies in respect to all demands. As such, waiting lines for places in daycare are the only equitable solution in a situation of lack of funds. The decision of the STF - determining that the local government create new places immediately, even if at the expenses of public funds designated to other areas - has change the way the Judiciary ruled in terms of public policies. In his vote, Associate Justice Celso de Melo pointed out that "although it is unquestionable the fact that Legislative and Executive Powers have the prerogative to formulate and execute public policies, it is possible for the Judiciary Power to determine their implementation, particularly in cases of public policies defined by the Constitution itself, whenever the competent government affect, with their omission, the efficacy and integrity of social and cultural rights constitutionally granted, through non-compliance with political and legal incumbency that are mandatorily assigned to them." The decision issue in Appeal no. 410,715 influenced the National Congress, that voted a Constitutional Amendment (no. 59/2009) and a bill (Law $12,796 / 2013$ ) determining universal access to daycare. It is important to notice that in this case, the court determines to the local education agencies the level of public expenditures to guarantee free daycare for all (the same had never happen in relation to other social rights such as health, a field where is quite common the private litigation, claiming to a certain individual asset - as medications, for example).

The Supreme Court also examines cases related to affirmative actions that raise new questions to consider. Cases concerning the judicial review of racial quotas (ADPF 186/DF) and university quotas for students coming from public schools (RE 597.285/RS) explore complex subjects in the continuing refinement of the rights of students in education. After these precedents, the federal state adopted legislation (Law 12 711/12) which provides for the distribution of student positions in higher education institutions maintained by the federal government.

\section{Conclusions}

For many decades, education law in Brazil changed very little. However, during the last 25 years, the situation has altered considerably and the transformation process is not over yet. Basically, these developments involve universal access to the educational system and the guarantee of the rights in education for all. The fact that they 
are being enforced by the courts, the provisions on the protection of the right to education became normative provisions rather than being considered programmatic provisions.

The effectiveness of the right to education through court decisions reveals new affirmative aspects of the rule of law in favor of citizenship rights and people participation, something especially important in a country with low perception rates of the importance of democratic institutions, and unaware of the Constitution normative strength. Undoubtedly, this is a signal of the quality of the Brazilian democracy since it revels the results of the democratic institutions' activity. It is also understood that judicial mechanisms for social rights protection can be extremely effective in situations where public policy arise directly from the Constitution, as seen in São Paulo State Prosecutor's Office v. the City of Santo Andre.

These findings suggest as a logical consequence, that the setting up of objectives, targets, and priorities under the constitution, combined with a clear division of roles, duties, and funds among the federative entities, and with a clear allocation of financial resources, enables the right to education being achieved in the medium term. This means that without the efficacy filter of the legislature, the constitutional provisions embody obligations which are thus considered directly accessible to private individuals and have to be immediately enforced by the state. From this perspective, if on the one hand the role of the courts still requires coping with practical issues, such meeting the timing of urgent claims, on the other hand it points to a path where constitutional hermeneutics can be carried out in a highly creative way in order to ensure fundamental rights.

However, the active role of the courts will only lead to concrete public policies and consequently to the true promotion of the right to education if the other Powers comply with court decisions. Besides, by favoring access over quality of education, the courts merely solves isolated disputes and causes the fragmentation of public policies, which should be aimed at more comprehensive development policy, including subjects as school choice and academic reforms. The same conclusion was pointed out by the Inter-American Development Bank Report of the David Rockefeller Center for Latin America Studies at Harvard University: "the formulation of educational policies in Latin America is disproportionately biased in favor of policies emphasizing increased access, rather than quality and efficiency."(IDB / Harvard, 2007, p. 224). Cases involving universal school access tend to decrease. Firstly, due to the precedent established by São Paulo State Prosecutor's Office v. the City of Santo Andre. Secondly, due to the issuance of constitutional and federal norms that ensure new rights (among which the right of access to childcare and the increase of mandatory basic education). 
The activity in the Courts shows that the right to Education in the Brazilian legal system is not an abstract provision. On the contrary, it consists in a set of objective and consequent determinations that may be applied to contingencies, situations and circumstances that happen in the social development, through the jurisprudential and doctrinal integration. The judicial path, in particular, to give effect to the right to Education, has been revealing new fields of affirmation of the democracy, to the benefit of citizenship rights and popular participation, what is particularly important in a country with low popular perception of the democratic institution value, and little knowledge of the regulatory force of the Constitution. Jurisprudence based on national legislation can also provide insights into the ways in which the justiciability of the right to education and enforcement could be strengthened.

\section{REFERENCES}

ALMOND, G.; VERBA, S. (1968). The civic culture: political attitudes and democracy in five nations. Princeton: Princeton University Press.

ASSIS, Luiz Gustavo Bambini de. Processo Legislativo e orçamento público: função de controle do Parlamento". 1. ed. São Paulo: Saraiva, 2012. v. 1. 297 p.

BID (Banco Interamericano de Desenvolvimento); Harvard University - David Rockefeller Center for Latin America Studies. A política das políticas públicas : progresso econômico e social na América Latina: relatório 2006. Rio de Janeiro: Elsevier; Washington, DC: BID, 2007.

BAURIES, Scott. "Is There an Elephant in the Room?: Judicial Review of Education Adequacy and the Separation of Powers in State Constitutions". Alabama Law Review, Vol. 61:4, 2010, pp. 701-772. Disponível em < http://uknowledge.uky.edu/law_facpub/31/>

BOBBIO, Norberto. A Era dos Direitos. São Paulo: Campus, 1992.

CONVERSE, P. E. (1972) The Human Meaning of Social Change. New York: Russel Sage Foundation.

COOMANS, Fons - Justiciability of the Right to Education, Erasmus Law Review, Vol. 2, No. 4, pp. 427-443, 2009.

CURY, C. R. J.; HORTA, J. S. B. e FÁVERO, O. (1996). A Relação Educação-Sociedade-Estado pela Mediação Jurídico Constitucional. In Fávero, O. (org.) A Educação nas Constituições Brasileiras: 1823-1988, Campinas: Ed. Autores Associados, pp. 05-30.

DAHL, R A. (1967). Pluralist democracy in the United States. Chicago: Rand McNally. 
DURHAM, E. R. "Democracia e educação: O ensino médio e o ENEM". Blog Qualidade de Democracia, São Paulo, 15/10/2012. Disponível em: <http://qualidadedademocracia.com.br/democracia-e-educacao-oensino-medio-e-o-enem/>

FAUSTO, Boris e Fernando Devoto, Brasil e Argentina - Um Ensaio de Historia Comparada (1850-2002), São Paulo: Editora 34, 2004, p. 50 e ss.

KEY, V. O. (1961) Public opinion and American democracy. New York: Alfred A. Knopf.

LAZARSFELD, P. F.; BERELSON, B. ; GAUDET, H. (1955). The people's choice. New York: Columbia University Press.

LIPSET, S. M. (1959). Some social requirements of democracy: economic development and political legitimacy. American Political Science Review, 53(1): pp. 69-105.

NEVES, Marcelo. A constitucionalização simbólica. 2. ed. São Paulo: Martins Fontes: 2007.

MCMAHON, W. W. (2002). Education and development: measuring the social benefits, Oxford: Oxford University Press

MARCILIO, Maria Luiza Marcílio, História da Educação em São Paulo e no Brasil, São Paulo: Imprensa Oficial, 2005.

MOISÉS, José Álvaro. Cultura política, instituições e democracia: lições da experiência brasileira. In Revista Brasileira de Ciências Sociais. Vol.23 N.66, São Paulo Fev. 2008. Disponível em <http:// dx.doi.org/10.1590/S0102-69092008000100002>.

MOISÉS, José Álvaro. Democracia e confiança: por que os cidadãos desconfiam das instituições públicas? São Paulo: Edusp, 2010.

PSACHAROPOULOS, G. (1988). Education and Development: A Review. The World Bank Research Observer, 3(1):100-116.

RANIERI, Nina Beatriz Stocco. Educação Superior, Direito e Estado na Lei de Diretrizes e Bases (Lei n 9.394/96). São Paulo: Edusp, Fapesp, 2000.

. 2009a. O Estado democrático de direito e o sentido da exigência de preparo da pessoa para o exercício da cidadania, pela via da educação. Tese (Livre docência), Faculdade de Direito da Universidade de São Paulo, São Paulo.

. 2009b. Os Estados e o Direito a Educação na Constituição de 1988 - Comentários acerca da jurisprudência do Supremo Tribunal Federal. In Direito à Educação: aspectos constitucionais. RANIERI, Nina Beatriz Stocco. (Coord.); RIGHETTI, Sabine (Org.). São Paulo: Edusp. 183.

. 2009c. O Supremo Tribunal Federal e o direito 
internacional à educação: a promoção indireta dos princípios e normas internacionais. In O STF e o direito internacional dos direitos humanos. AMARAL JÚNIOR, Alberto do; JUBILUT, Liliana Lyra (Orgs). São Paulo: Quartier Latin.

RUSSO, Charles J. Reuter's - The law of public education. 7TH ed. New York: Thomson Reuters Foundation Press, 2009.

SADEK, Maria Tereza. 2004. "Judiciário: mudanças e reformas". In: Estudos Avançados, vol. 18 no. 51, São Paulo, mai./ago., pp. 79-101. Disponível em: < http://www.scielo.br/pdf/ea/v18n51/a05v1851.pdf >

. (2011). "Judiciário e arena pública: um olhar a partir da ciência política". In: O controle jurisdicional de Políticas Públicas. GRINOVER, Ada Pellegrini; WATANABE, Kazuo (Coords.). São Paulo: Método.

SALLES, Carlos Alberto. Duas faces da proteção judicial dos direitos sociais no Brasil. In: As grandes transformações do Processo Civil Brasileiro: estudos em homenagem ao Professor Kazuo Watanabe. SALLES, Carlos Alberto de. (org.) São Paulo: Quartier Latin, 2009, p. 792.

. "Coisa julgada e extensão dos efeitos da sentença em matéria de direitos sociais constitucionais." In Em defesa de um novo sistema de processos coletivos: Estudos em Homenagem a Ada Pellegrini Grinover. GOZZOLI, Maria Clara; CIANCI, Mirna; CALMON, Petrônio; QUARTIERI, Rita. (Coord.). São Paulo: Saraiva, 2010.

SINGH, Kishore - Justiciability of the right to education, Report of the Special Rapporteur on the right to education. United Nations, General Assembly- A/HRC/23/35, 10 May 2013.

TAYLOR, Matthew M.. Judging policy - courts and policy reform in democratic Brazil. Standford: Standford University Press, 2008.

O Judiciário e as políticas públicas no Brasil. In Dados, Rio de Janeiro, v. 50, n. 2, 2007. Disponível em $<$ http://www.scielo.br/ scielo.php?script $=$ sci_arttext\&pid $=$ S0011-52582007000200001\&lng $=$ en\&nrm $=$ iso $>$.

TOMASEVSKI, Katarina. 2001a. "Removing obstacles in the way of the right to education". In Right to Education Primers No. 1. Gothenburg: Novum Grafiska.

2001b. "Free and compulsory education for all children: The gap between promise and performance". In Right to Education Primers No. 2. Gothenburg: Novum Grafiska.

. 2001c. "Human rights obligations: making education available, accessible, acceptable and adaptable." In Right to education 
primers $\mathrm{n}^{\mathbf{0}}$ 3. Gothenburg: Novum Grafiska.

. 2001d. "Human rights in education as prerequisite for human rights education" In Right to education primers $n^{\circ} 3$. Gothenburg: Novum Grafiska.

2003. Education denied - costs and remedies. London, New York: Zed Books.

VIECELLI, R. D. C. "A efetividade do direito à educação e a justiciabilidade das políticas públicas na jurisprudência do STF (19882011)142," Revista de Direito Educacional, ano 3, vol. 5, jan-jun 2012, pp. 211- 243.

VIECELLI, R. D. C. "O ciclo da Judicialização das Políticas Públicas: A Lei de Diretrizes e Bases Da Educação Nacional de 1996 e os efeitos indiretos externos das decisões do STJ E STF"143, Revista de Direito Educacional, ano 3, vol. 6, jul-dez 2012, pp. 261 a 283.

DUARTE, Clarice Seixas. Direito público subjetivo e políticas educacionais. São Paulo em Perspectiva, São Paulo, v. 18, n.2, p. 113118, 2004.

SILVA, Virgílio Afonso da. O Judiciário e as politicas públicas: entre transformação social e obstáculo à realização dos direitos sociais. p. 587-599. In: SOUZA NETO, Cláudio Pereira de; SARMENTO Daniel (Org.). Direitos sociais: fundamentos, judicialização e direitos sociais em espécie. Rio de Janeiro: Lumen Juris, 2008.

SILVEIRA, Adriana Dragone. Atuação do Tribunal de Justiça de São Paulo com relação ao direito de crianças e adolescentes à educação. Revista Brasileira de Educação, v. 17, p. 353-497, 2012. 